\title{
MEMAHAMI INVESTASI BERBASIS MINYAK CINA DI SUDAN: ANALISIS INTERAKSI STRATEGIS CINA PADA SITUASI KONFLIK
}

\author{
Fajar Ajie Setiawan \\ Fakultas Ilmu Sosial dan Komunikasi \\ Universitas Wanita Internasional \\ ajie.hatadji@gmail.com
}

\begin{abstract}
Abstrak
Perkembangan pesat perekonomian Cina khususnya dalam dua dekade terakhir mendorong tingginya ketergantungan Cina akan impor minyak bumi melebihi kapasitas produksi domestiknya. Cina untuk pertama kalinya melewati Amerika Serikat sebagai importir minyak terbesar di dunia pada tahun 2015 dengan kawasan Afrika khususnya negara-negara 'bermasalah' seperti Sudan menjadi tujuannya. Investasi berbasis minyak Cina di Sudan kemudian menjadi perhatian dunia internasional karena kebijakan non-interferensi Cina dianggap tidak memedulikan permasalahan domestik Sudan. Penelitian ini berupaya untuk menjelaskan bagaimana investasi berbasis minyak Cina di Sudan dengan fokus analisis terhadap interaksi strategis antar negara yaitu Cina dengan Sudan yang dilanda konflik dengan menggunakan tiga variabel analisis yaitu kepentingan negara, spesifikasi setting strategis, dan perhatian terhadap faktor ketidakpastian. Hasil analisis memperlihatkan bahwa kebutuhan minyak sebagai penggerak pertumbuhan ekonomi Cina merupakan kepentingan krusial sehingga menjadi prioritas yang dijalankan oleh SOEs Cina sebagai instrumen strategis berdasarkan kebijakan "China First" yang permisif terhadap isu domestik.
\end{abstract}

Kata Kunci: investasi minyak; politik luar negeri cina; konflik sudan; ekonomi politik internasional

\section{Abstract}

The rapid economic development of PRC especially during the last two decades has prompted its dependence on oil imports exceeding its domestic production. China for the first time exceeded US as the biggest oil importer in 2015 with Africa particularly 'troubled' countries such as Sudan as its destination. China's oilbased investment in Sudan later becomes international concern since China's non-interference policy was perceived as ignoring Sudan's domestic problems. This research attempts to explain China's oil-based investment in Sudan with focus of analysis on China's strategic interaction with conflict-troubled Sudan using three analytical variables: the identification of state interest, the specification of strategic setting, and the attention to the role of uncertainty. Analysis result shows that China's need for oil to secure its economic growth is China's vital interest as being prioritized by its SOEs as China's strategic instrument based on 'China First' policy that is permissive towards Sudan's domestic issue.

Keywords: oil investment; china's foreign policy; sudan conflict; IPE

\section{Pendahuluan}

Meningkatnya kebutuhan sumber energi minyak bumi untuk menstabilkan pertumbuhan ekonomi dan berkembangnya populasi yang sangat pesat mendorong Cina untuk memperluas pencariannya akan alternatif sumber-sumber minyak bumi selain Rusia dan Timur Tengah. Faktor pendorong hal ini sangat gamblang: pertumbuhan Produk Domestik Bruto (PDB) Cina yang stabil di angka $8-10 \%$ dalam kurun 2000-2010 membutuhkan suplai energi tanpa gangguan. ${ }^{1}$ Selain itu, stabilitas

\footnotetext{
1 Wayne M. Morrison, China's Economic Rise: History, Trends, Challenges, Implications for the United States, (Washington D.C.: U.S. Congressional Research Service, 2017)
}

suplai energi merupakan kepentingan nasional Cina yang utama, terlihat dari kekhawatiran mantan Presiden $\mathrm{Hu}$ Jintao yang ia sebut sebagai "The Malacca Dilemma", dependensi Cina yang sangat tinggi terhadap jalur perdagangan laut Selat Malaka yang membawa $80 \%$ minyak impor dari Timur Tengah dan Afrika. $^{2}$ Hal ini mendorong Cina untuk mencari minyak bumi ke luar negeri; Cina saat ini menjadi importir minyak terbesar di atas Amerika Serikat. Afrika menjadi tujuan StateOwned Enterprise (SOE) Cina terutama negara-negara 'bermasalah' seperti Sudan serta

\footnotetext{
${ }^{2}$ Shaofeng Chan, "China's Self-Extrication from the "Malacca Dilemma" and Implications", International Journal of China Studies 1, No. 1 (2010): 1-24.
} 
120 Fajar Ajie Setiawan Memahami Investasi Berbasis Minyak Cina Di Sudan: Analisis Interaksi Strategis Cina Pada Situasi Konflik

menggunakan kebijakan "China First" yang permisif terhadap isu-isu domestik di Sudan. Keterlibatan Cina di Sudan kemudian menjadi perhatian dunia internasional karena kebijakan non-interferensi Cina dianggap tidak memedulikan permasalahan yang terjadi di Sudan seperti pelanggaran hak asasi manusia di dalam konflik Sudan Selatan, yang terlihat dari penolakan Beijing untuk menurunkan penjaga perdamaian di Darfur, namun dengan cepat menurunkan 400 pasukannya untuk menjaga sumur minyaknya di Sudan ketika situasi politik dan keamanan semakin mengancam sumur minyak Cina di Sudan. ${ }^{3}$

Penelitian ini berupaya untuk mengeksplorasi pertanyaan penelitian "Bagaimana interaksi strategis Cina dengan Sudan terkait dengan investasi berbasis minyak Cina di tengah konflik Sudan?". Cina merupakan salah satu fokus utama di dalam kajian IPE global, sehingga Cina menjadi sebuah sumber potensial bagi penelitian dan pengembangan ilmu hubungan internasional, khususnya IPE. ${ }^{4}$ Penelitian ini dilakukan menggunakan teori interaksi strategis antar negara dan internasional sebagai sebuah pendekatan positivis di dalam kajian IPE. Berdasarkan kepada hal ini, bagian pertama penelitian ini adalah pendahuluan dan penjabaran latar belakang permasalahan, pertanyaan penelitian, serta struktur penelitian. Bagian kedua dari penelitian ini akan menjelaskan mengenai pendekatan Ekonomi Politik Internasional di dalam studi Hubungan Internasional, termasuk perdebatan di dalamnya, serta menjelaskan mengenai teori interaksi strategis antar negara yang diusulkan oleh Frieden dan Martin untuk memahami

\footnotetext{
${ }^{3}$ Phillip Manyok, “Oil and Darfur's Blood: China's Thirst for Sudan's Oil", Journal of Political Science \& Public Affair 4, (2016): 189.

${ }^{4}$ Gregory Chin, Margaret M. Pearson, dan Wang Yong, "Introduction - IPE with China's characteristics", Review of International Political Economy 20, 6 (2013): 1145-1164.
}

kebijakan ekonomi luar negeri sebuah negara di dalam ekonomi politik internasional. ${ }^{5}$

Bagian ketiga akan membahas mengenai investasi Cina di Sudan terkait erat dengan kebutuhan konsumsi energi minyak domestik di Cina. Bagian ini menjelaskan mengapa Sudan menjadi salah satu fokus perhatian bagi Cina dan bentuk-bentuk investasi Cina di Sudan yang sangat erat berhubungan dengan kepentingan minyak Cina. Bagian ini juga akan menjelaskan mengenai dampak-dampak yang ditimbulkan oleh hubungan Cina-Sudan terkait dengan investasi Cina tersebut. Dampakdampak tersebut dibatasi/dikelompokkan ke dalam dua kategori: pembangunan dan keamanan sebagai variabel materialistis yang menjadi fokus pengamatan pendekatan positivisme. ${ }^{6}$ Penelitian ini tidak mencoba menganalisis variabel-variabel seperti pengetahuan bersama (shared knowledge), identitas (identity), ide (idea), atau budaya strategis (strategic culture) yang diusulkan oleh konstruktivis. ${ }^{7}$

Penelitian ini kemudian mencoba menganalisis interaksi faktor domestik dan internasional Cina di dalam bagian keempat yang berdasarkan kepada variabel kepentingan ekonomi dan institusi politik Cina sebagai faktor domestik serta variabel interaksi strategis antar negara dan institusi internasional

\footnotetext{
${ }^{5}$ Frieden, Jeffry, dan Lisa L. Martin.. "International Political Economy: Global and Domestic Interactions." Dalam Political Science: The State of Discipline, oleh Ira Katznelson dan Helen Miller, 118-146. (Boston: W. W. Norton \& Company, 2001)

6 Jeffry A. Frieden dan Ronald Rogowski. 1996. "The Impact of the International Economy on National Policies: An Analytical Overview." Dalam Internationalization and Domestic Politics, disunting oleh Robert O. Keohane dan Helen V. Milner, 25-47. Cambridge: Cambridge University Press.

${ }^{7}$ Kajian lebih jauh terkait dengan hal ini, contohnya adalah: Rawi Abdelal, Mark Blyth, dan Craig Parsons, Constructing the International Economy, (New York: Cornell University Press, 2010);
} 
121 Fajar Ajie Setiawan Memahami Investasi Berbasis Minyak Cina Di Sudan: Analisis Interaksi Strategis Cina Pada Situasi Konflik

sebagai faktor interaksi internasional. Bagian keempat ini kemudian menghasilkan kesimpulan yang akan dijelaskan pada bagian kelima.

\section{Teori Ekonomi Politik Internasional}

Keterikatan studi hubungan internasional dan ekonomi internasional semakin mendapatkan perhatian dunia melalui munculnya pendekatan International Political Economy (IPE) atau ekonomi politik internasional sebagai pendekatan yang menggabungkan kedua studi untuk menjelaskan fenomena-fenomena hubungan internasional kontemporer. Pendekatan ini mencoba memahami bagaimana aktor politik (negara, individual, institusi) mempengaruhi ranah internasional yang berdampak kepada kebijakan dan interaksi ekonomi yang juga kemudian kembali mempengaruhi sektor politik domestik. ${ }^{8}$ Secara singkat, Thomas Oatley mendefinisikan IPE sebagai sebuah kajian yang mempelajari bagaimana faktor politik mempengaruhi perkembangan ekonomi global dan bagaimana ekonomi global kemudian mempengaruhi politik. ${ }^{9}$ Keohane dan Nye dianggap sebagai akademisi yang 'membukakan' jalan bagi pengamat dengan kerangka pemikiran $\mathrm{HI}$ untuk menganalisis secara sistematis hubungan perekonomian internasional sebagai ekstensi dari kajian keHI-annya. ${ }^{10}$

\section{Paradigma Ekonomi Tradisional dan IPE Kontemporer}

Studi ekonomi politik internasional pada umumnya terbagi menjadi tiga paradigma

\footnotetext{
${ }^{8}$ Joan E. Spero, dan Jeffrey A. Hart, The Politics of International Economic Relations, (5 ${ }^{\text {th }}$. London: Routledge, 1997), hal. 2-4.

9 Thomas H. Oatley. International Political Economy. ( $5^{\text {th }}$. New York: Routledge, 2016). Hal. 1-2.

${ }^{10}$ Benjamin J. Cohen. "The Multiple Traditions of American IPE." Dalam Routledge Handbook of International Political Economy (IPE), disunting oleh Mark Blyth. (New York: Routledge. 2009). Hal. 23-35.
}

ekonomi tradisional/ neoklasik yang berfokus pada perdebatan mengenai peran dan signifikansi pasar di dalam pengorganisasian masyarakat dan ekonomi yaitu Merkantilisme (atau juga disebut dengan nasionalisme, atau realisme) ${ }^{11}$, Liberalisme, dan Marxisme $^{12}$. Kajian literatur mengenai merkantilisme sangat bervariasi dan luas, namun secara umum terbagi menjadi merkantilisme klasik dan merkantilisme modern. Merkantilisme klasik berargumen bahwa: 1) kekuatan nasional sebagian besar berasal dari kekayaan; 2) surplus perdagangan dapat membawa kekayaan dari internasional ke dalam domestik; dan 3) perindustrian merupakan aktivitas ekonomi yang lebih baik daripada non-industri dan agrikultur. ${ }^{13}$ Sedangkan merkantilisme 'modern', berargumen bahwa: 1) kekuatan ekonomi hanya merupakan komponen penting di dalam kekuatan nasional; 2) perdagangan harus berfokus kepada ekspor dengan pemerintah mengurangi impor sebisa mungkin; dan 3) beberapa bentuk industri lebih baik daripada yang lain, khususnya industri berteknologi tinggi. ${ }^{14}$

Liberalisme bersumber dari pemikiranpemikiran market-centric seperti Adam Smith (the invisible hands) dan David Ricardo (comparative advantage), yang mencoba mengubah dominasi negara di bidang ekonomi dengan berargumen bahwa: 1) tujuan aktivitas ekonomi adalah untuk memperkaya individu, bukan meningkatkan kekuatan negara; 2)

11 Gilpin di dalam bukunya, Global Political Economy: Understanding the International Economic Order, berargumen bahwa meskipun seluruh nasionalis adalah realis, tidak semua realis menganut pandangan normatif nasionalisme. Bacaan lebih lanjut: Robert Gilpin, Global Political Economy: Understanding the International Economic Order. (New Jersey: Princeton University Press. 2001)

12 Robert Gilpin. The Political Economy of International Relations. (New Jersey: Princeton University Press, 1987). Hal. 25-26.

${ }^{13}$ Thomas H. Oatley. Hal. 8-9.

${ }^{14}$ Ibid. 
122 Fajar Ajie Setiawan Memahami Investasi Berbasis Minyak Cina Di Sudan: Analisis Interaksi Strategis Cina Pada Situasi Konflik

negara tetap mendapatkan sesuatu dari perdagangan internasional, tanpa melihat surplus tidaknya; 3) negara mendapatkan kekayaan bukan dari industri tertentu, tetapi dari perdagangan manufaktur yang murah diproduksi secara lokal dengan manufaktur yang mahal bila diproduksi secara lokal. ${ }^{15}$ Dengan demikian, liberalisme mengkritik merkantilisme dengan berargumen bahwa pemerintah justru harus seminimal mungkin mempengaruhi sektor ekonomi karena hanya akan mengurangi kesejahteraan nasional.

Paradigma ketiga dalam pemikiran tradisional IPE adalah Marxisme yang bersumber dari kritik terhadap kapitalisme yang berargumen bahwa: 1) ada kecenderungan alami akan terjadinya konsentrasi kapital melalui kompetisi ekonomi; 2) kapitalisme akan mendorong penurunan keuntungan/profit melalui melimpahnya produksi; dan 3) kapitalisme akan menghasilkan ketidakseimbangan antara ketersediaan produksi dengan daya beli masyarakat. Joseph Schumpeter menambahkan bahwa ketika Liberalisme berfokus kepada sistem kapitalis sehari-hari, Marxisme berfokus kepada dinamika jangka panjang dari sistem kapitalis ini. ${ }^{16}$

Secara umum, ketiga paradigma tradisional IPE mempengaruhi tiga teori IPE kontemporer. Yang pertama adalah Teori Ekonomi Ganda (Dual Economy Theory), yang dipengaruhi oleh liberalisme ekonomi. Teori ini menganggap terjadinya evolusi pasar sebagai respons terhadap dorongan universal untuk meningkatkan efisiensi dan memaksimalkan kekayaan. Yang kedua, yang sangat dipengaruhi oleh Marxisme, seringkali diidentifikasikan sebagai Teori Sistem Dunia

15 Eric Helleiner. "Economic Nationalism as a Challenge to Economic Liberalism? Lessons from the 19th Century." International Studies Quarterly 46, No. 3 (2002): 307-329.

16 Robert Gilpin, Global Political Economy: Understanding the International Economic Order, Op.cit.
(World System Theory) yang berargumen bahwa pasar dunia pada dasarnya adalah sebuah mekanisme untuk mengeksploitasi ekonomi negara-negara berkembang oleh ekonomi kapitalis maju. Ketiga, erat tapi tidak sepenuhnya terkait dengan Nasionalisme/Realisme karena ada beberapa pandangan Liberalisme yang mendukung teori ini, dikenal sebagai Teori Stabilitas Hegemoni (Hegemonic Stability Theory) yang menafsirkan kemunculan dan aktivitas ekonomi internasional modern berdasarkan kepada kekuatan liberal yang dominan. ${ }^{17}$

Terlepas dari perdebatan mengenai definisi IPE, dalam dua puluh tahun terakhir studi mengenai IPE cenderung memiliki konsensus terkait dengan teori, metode, kerangka analisis, dan pertanyaan penting yang menjadi dasar dari studi ini. Pernyataan ini dimaksudkan bahwa perdebatan di dalam studi IPE kontemporer lebih berfokus kepada perdebatan klaim produktif, baik yang berbasis teoritis maupun empiris, dan tidak lagi pada benturan paradigmatis. ${ }^{18}$ Gilpin berargumen bahwa meskipun studi tentang IPE sangat bergantung pada teori dan wawasan ekonomi neoklasik, namun IPE dan ekonomi neoklasik mengajukan pertanyaan penelitian yang berbeda karena menerapkan cara analisis yang berbeda. Ketika kajian ekonomi tradisional terutama berkaitan dengan pertanyaan mengenai efisiensi dan pertukaran ekonomi, IPE berfokus kepada pertanyaan-pertanyaan dalam isu-isu yang lebih luas, seperti contohnya adalah distribusi keuntungan dari aktivitas pasar, peran institusi dan rezim internasional (berbeda dengan neoklasik yang berfokus hanya kepada pasar), dan otonomi

\footnotetext{
17 Robert Gilpin. The Political Economy of International Relations. Op.cit. Hal. 66.

18 Jeffry Frieden, dan Lisa L. Martin, "International Political Economy: Global and Domestic Interactions", di dalam Political Science: The State of Discipline, ed. Ira Katznelson dan Helen V. Milner, (Harvard: W. W. Norton \& Company, 2001), hal. 118-146.
} 
123 Fajar Ajie Setiawan Memahami Investasi Berbasis Minyak Cina Di Sudan: Analisis Interaksi Strategis Cina Pada Situasi Konflik

negara vis-a-vis interdependensi di dalam ekonomi internasional. ${ }^{19}$

\section{Teori Interaksi Strategis Antar Negara}

Salah satu perkembangan studi ekonomi politik internasional kontemporer sebagai usaha untuk menjelaskan keterkaitan fenomena ekonomi dan politik juga menekankan kepada analisis hubungan antara faktor ekonomi politik domestik di dalam kebijakan ekonomi luar negeri dan peran dari hubungan strategi negara-negara di level internasional. Inti dari analisis ini adalah interaksi antara dimensi domestik dengan dimensi internasional di dalam pembentukan kebijakan luar negeri. ${ }^{20}$ Dimensi ekonomi politik domestik mencakup dua faktor, yaitu: 1) kepentingan ekonomi, dan 2) institusi politik; sedangkan dimensi interaksi internasional memiliki dua faktor yaitu 1) interaksi strategis antar negara, dan 2) institusi internasional.

Penelitian ini akan menggunakan teori interaksi strategis antar negara untuk menjelaskan investasi berbasis minyak yang dilakukan Cina di Sudan. Untuk melakukan hal tersebut ada tiga variabel analisis yang perlu untuk dikaji untuk dapat menjelaskan tujuan penelitian, yaitu: 1) identifikasi kepentingan negara; 2) spesifikasi setting strategis; dan 3) perhatian terhadap ketidakpastian. ${ }^{21}$

Pertama, proses identifikasi kepentingan negara dan dinamika perubahannya dapat dilakukan dengan berbagai cara. Pertama, adalah dengan melihat kepada pola kepentingan dan variasi dari kepentingan tersebut di berbagai negara dan isu. Salah satu metode adalah dengan melihat derajat kepentingan bersama. Ketika negara memiliki tingkat kepentingan bersama yang tinggi, fokus analisis berpusat kepada faktor-faktor yang mendorong atau mencegah upaya realisasi

\footnotetext{
${ }^{19}$ Robert Gilpin, Global Political Economy. Op.cit. Hal. 77-78.

${ }^{20}$ Ibid.

${ }^{21}$ Jeffry Frieden, dan Lisa L. Martin. Op.cit.
}

kepentingan bersama tersebut. Namun apabila kepentingan bersama rendah, analisis difokuskan kepada faktor yang mempengaruhi hasil di dalam situasi dengan derajat konfliktual yang tinggi (seperti kemungkinan pemutusan hubungan atau penggunaan militer). Kedua, adalah dengan melihat kepada posisi negara tersebut di dalam sistem internasional, terkait dengan distribusi kekuasaan.

Kedua adalah variabel spesifikasi setting strategis yang dapat dipahami sebagai struktur hubungan/interaksi sebuah negara baik dengan negara lain maupun dengan sistem internasional. Interaksi bilateral menciptakan berbagai kendala dan peluang yang berbeda daripada interaksi yang melibatkan beberapa negara, atau interaksi dengan sistem internasional yang melibatkan banyak negara. Sistem internasional juga mempengaruhi prioritas masalah yang akan dipertimbangkan atau isu mana yang akan dipertimbangkan.

Ketiga adalah perhatian terhadap ketidakpastian, dimana sebuah negara hanya memiliki perkiraan terhadap preferensi atau pilihan kebijakan dari negara lain, atau situasi yang dihadapi. Negara pada awalnya membentuk strategi berdasarkan perkiraan terhadap tindakan negara lain atau situasi di negara lain. Seiring munculnya interaksi, informasi mengenai perkiraan ini akan semakin lengkap dan jelas sehingga membantu negara untuk mempertimbangkan ulang strateginya.

\section{Investasi Berbasis Minyak Cina di Sudan}

Melonjaknya harga minyak dilihat oleh Cina sebagai sebuah dependensi yang membahayakan, terutama karena Cina merupakan importir terbesar di dunia di atas Amerika Serikat. Keadaan ini membuat Cina memiliki kerawanan energi dan memiliki ketergantungan kepada hal yang berada di luar kontrol Beijing. Hal ini mendorong Cina untuk membentuk minyak bumi sebagai kepentingan nasional vital dan mencari sumber minyak bumi ke daerah yang seringkali ditinggalkan 
124 Fajar Ajie Setiawan Memahami Investasi Berbasis Minyak Cina Di Sudan: Analisis Interaksi Strategis Cina Pada Situasi Konflik

oleh negara-negara Barat, seperti negaranegara di Afrika.

Afrika seringkali dilihat sebagai sebuah benua yang 'tertinggal' di dunia; tingginya jumlah negara-negara yang bermasalah seperti perang sipil yang berkepanjangan, kemiskinan dan kelaparan, rezim otoriter yang seringkali melanggar hak-hak asasi manusia. Faktorfaktor tersebut memberikan dampak ketidakstabilan domestik bagi negara-negara di Afrika sehingga seringkali melemahkan posisi tawarnya di dunia internasional dan kemampuan diplomasinya bila dibandingkan dengan negara-negara lain seperti negaranegara Eropa dan Asia Timur. Hal ini membuka celah bagi Cina untuk menjalin kerjasama dengan negara-negara Afrika mengingat Cina menawarkan hubungan noninterferensi dengan rekan-rekannya di Afrika. Keterbukaan negara-negara Afrika terhadap Cina mendorong tingginya investasi Cina di Afrika, seperti Foreign Direct Investment (FDI) Cina di Afrika yang pada tahun 2005 mencapai US $\$ 1.6$ triliun. Peta investasi berikut memberikan gambaran persebaran FDI Cina di Afrika yang cukup tinggi.

Gambar 1. Persebaran FDI Cina di Afrika pada 2005

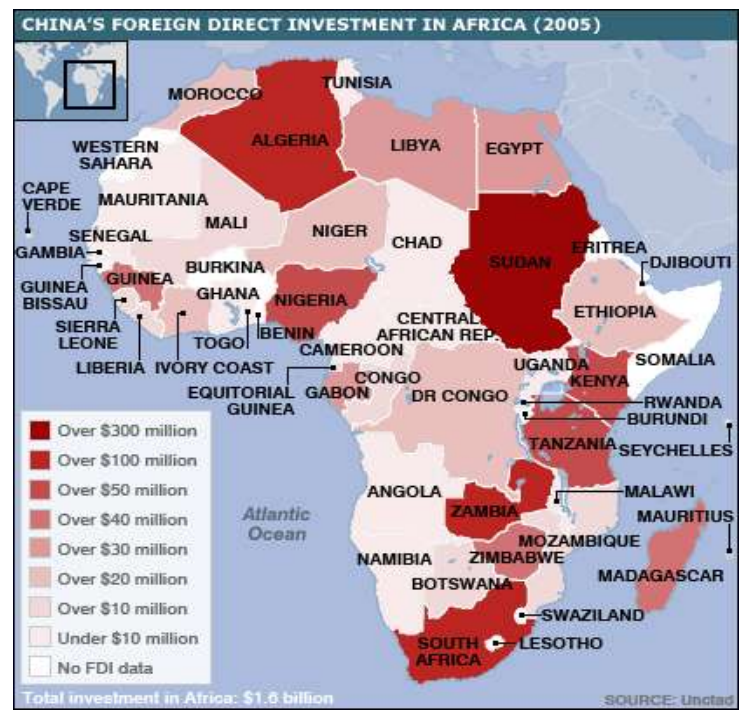

Sumber: Disadur dari $\mathrm{BBC}^{22}$

Gambar di atas memperlihatkan persebaran FDI Cina di Afrika pada tahun 2000-2005 yang berjumlah US\$1,6 trilyun. Sudan menjadi negara penerima terbesar di Afrika dengan US\$300 juta diinvestasikan oleh Cina yang memperlihatkan hubungan ekonomi yang kuat antara Cina dengan Sudan.

Satu hal lain yang menjadikan Afrika mulai diperhitungkan Cina adalah keberadaan cadangan minyak yang luar biasa besar. Afrika mulai dilirik sebagai sumber minyak alternatif bagi Cina dengan cadangan minyak yang sudah terbukti dimiliki Afrika adalah sebesar 132.4 milyar bpd (barrels per day/barel per hari), $8 \%$ dari cadangan minyak dunia saat ini dan angka ini merupakan sebagian kecil dari cadangan minyak yang diperkirakan ada di Afrika. Meskipun memiliki sumber cadangan minyak yang diperhitungkan dan kemungkinan cadangan minyak yang lebih besar, sumber minyak di Afrika hanya dimiliki oleh sebagian kecil negara-negara di Afrika. Tabel berikut akan menjelaskan persebaran cadangan minyak di Afrika (yang sudah terbukti).

Tabel 1. Cadangan Minyak Negara-Negara Afrika

\begin{tabular}{lll}
\hline Negara & $\begin{array}{l}\text { (dalam } \\
\text { milyar } \\
\text { barel) }\end{array}$ & $\begin{array}{l}\text { \% dari total } \\
\text { Cadangan } \\
\text { Afrika }\end{array}$ \\
\hline Aljazair & 12.2 & $9,2 \%$ \\
Angola & 13.5 & $10,2 \%$ \\
Chad & 1.5 & $1,1 \%$ \\
Republik & 1.9 & $1,4 \%$ \\
Kongo & & \\
Mesir & 4.3 & $3,2 \%$ \\
Guinea & 1.7 & $1,3 \%$ \\
Ekuator & & \\
Gabon & 3.7 & $2,8 \%$ \\
Libya & 47.1 & $35,6 \%$ \\
\hline
\end{tabular}

${ }^{22}$ BBC, China in Africa: Developing ties, BBC News, diakses melalui http://news.bbc.co.uk/1/hi/world/africa/7086777.s tm pada 6 September 2017 
125 Fajar Ajie Setiawan Memahami Investasi Berbasis Minyak Cina Di Sudan: Analisis Interaksi Strategis Cina Pada Situasi Konflik

\begin{tabular}{|c|c|c|}
\hline Nigeria & 37.2 & $28,1 \%$ \\
\hline Sudan & 6.7 & $5,1 \%$ \\
\hline Tunisia & 0.4 & 0.3 \\
\hline Negara Afrika & 2.2 & 1.7 \\
\hline
\end{tabular}

Tabel di atas menjelaskan persebaran cadangan minyak di Benua Afrika. Dapat dilihat bahwa Libya memiliki jumlah cadangan minyak terbesar dengan 47.1 milyar bpd per tahun 2011. Nigeria menjadi negara kedua dengan cadangan minyak terbesar di Afrika dengan jumlah 37.2 milyar bpd diikuti oleh Angola, Aljazair, Sudan, dan negara-negara lainnya. Bila dibandingkan, negara-negara pemilik cadangan minyak terbesar seperti Libya, Nigeria, dan Aljazair merupakan negara-negara yang relatif stabil dan memiliki hubungan yang dekat dengan dunia Barat, berbeda dengan Angola dan Sudan yang dianggap masih memiliki kasus pelanggaran hak asasi manusia sehingga 'ditinggalkan' oleh dunia Barat. Sudan bahkan mendapatkan sanksi ekonomi dari dunia Barat terkait dengan kasus pelanggaran hak asasi manusia yang berat di Darfur yang mendorong terjadinya isolasi dari dunia Barat. Hal ini memberikan celah bagi Cina untuk membuka jalur kerjasama dengan negara-negara yang terisolir seperti Sudan sehingga mendapatkan sambutan yang hangat. ${ }^{23}$

\section{Investasi di Sektor Produksi Minyak}

Cadangan minyak telah diketahui sejak lama oleh masyarakat Sudan tetapi kapasitas finansial yang terbatas, diantara beberapa hal lainnya, telah menghambat usaha pemerintah untuk mengekstraksi cadangan minyak mereka. Proses ekstraksi mulai dilakukan ketika Chevron Corporation menjadi yang pertama melakukan usaha tersebut pada 1960an namun kemudian meninggalkan usahanya pada 1980an setelah meletusnya perang saudara di Sudan. Cina masuk menjadi partner energi

23 Daniel Large, China's Sudan Engagement: Changing Northern and Southern Political

Trajectories in Peace and War, The China Quarterly, 199 (2009) 610-626.

\begin{tabular}{|c|c|c|}
\hline lainnya & & \\
\hline Total Afrika & 132.4 & 100 \\
\hline
\end{tabular}

minyak Sudan setelah Sudan mendapatkan sanksi dari Amerika Serikat pada tahun 1990an terkait dengan isu pelanggaran hak asasi manusia. Sanksi ekonomi ini memberikan peluang untuk kehadiran Cina di Sudan yang cenderung menjadi pemain tunggal di sektor eksplorasi minyak di Sudan. ${ }^{24}$ Cina, yang mengimplementasikan kebijakan noninterferensi, hadir melalui sahamnya di Greater Nile Petroleum Operating Company (GNPOC), sebuah kerjasama internasional yang 40\% sahamnya dimiliki oleh Cina. GNPOC adalah satu-satunya dari dua proyek investasi Cina hingga 2010 yang menghasilkan 100,000 BPD selain AktobeMunaiGas di Kazakhstan. Saham ini dimiliki oleh SOE Cina yaitu China National Petroleum Company (CNPC) yang kemudian berkolaborasi dengan Kementerian Energi Sudan untuk menanamkan investasinya sebesar US\$300juta di sumur minyak Heglig dan Unity untuk melipatgandakan hasil produksinya. Walaupun jumlah tetapnya tidak dapat diketahui, Cina melalui CNPC diperkirakan telah menginvestasikan lebih dari US\$4 triliun dalam bentuk investasi aktif dari total US10\$ triliun investasi Cina di ranah eksplorasi minyak di Sudan. ${ }^{25}$

Konsorsium GNPOC di bawah CNPC saat ini sedang berusaha melakukan ekspansi untuk mencari dan memproduksi minyak di Sudan. Beberapa kilang minyak baru dibangun, dengan investasi Cina, di Blok 4 serta Thar Jath dan Mala Field di Blok 5A di Sudan

\footnotetext{
24 International Crisis Group. China's New Courtship in South Sudan. Africa Report, (Brussels: International Crisis Group, 2012)

25 US-China Economic and Security Review Commission. China's Overseas Investment in Oil and Gas Production. Government Publication, (Washington D.C.: Eurasia Group, 2006).
} 
126 Fajar Ajie Setiawan Memahami Investasi Berbasis Minyak Cina Di Sudan: Analisis Interaksi Strategis Cina Pada Situasi Konflik

Selatan. Untuk mentransportasikan hasil eksplorasi ini, China Petroleum and Chemical Corporation (Sinopec) sebagai SOE yang beroperasi di bidang hilir telah membangun pipa minyak dari blok-blok tersebut yang berada di daerah Sudan selatan menuju Pelabuhan Sudan yang berada di Laut Merah di Sudan utara. Di sana pun telah dibangun terminal tanker ekspor oleh China Petroleum Engineering Construction Group (CPECG) seharga US\$215 juta yang berasal juga dari investasi Cina.

\section{Resource-backed Development Loans}

Selain di sektor eksplorasi dan produksi minyak, Cina juga melancarkan hubungannya dengan Sudan dengan menawarkan pinjaman dan bantuan luar negeri sebagai strategi Cina untuk membangun kepercayaan dan meningkatkan posisi tawarnya dengan pemerintah Sudan. CNPC bekerjasama dengan pemerintah Sudan untuk membangun infrastruktur melalui proyek-proyek senilai US\$1triliun. SOE milik pemerintah Cina seringkali bertindak sebagai pemimpin lapangan dari proyek-proyek pembangunan infrastruktur di Sudan ini yang walaupun 'tidak terlalu menguntungkan' bagi Cina namun memberikan Cina posisi tawar yang lebih kuat terhadap Sudan. Sebagai contoh adalah proyek Harbin Power Company yang mendapatkan pinjaman dari Bank Sentral Cina untuk meningkatkan kapasitas hidroenergi serta jalur transmisi sepanjang 1,700 kilometer. Pemerintah Cina juga menawarkan pinjaman kepada Sudan untuk meningkatkan kapabilitas nasional, seperti pinjaman US\$60juta untuk meningkatkan kapabilitas kilang minyak Sudan. Dalam kurun 2002-2006 pinjaman yang diberikan pemerintah Cina di estimasi sebesar US\$1triliun yang digunakan untuk membangun proyek-proyek seperti pembangkit dan peningkatan kapasitas listrik, peralatan air, irigasi, pengeboran minyak, dan Pelabuhan Sudan.
Pinjaman-pinjaman ini kemudian akan dilunasi oleh pemerintah Sudan dalam bentuk minyak mentah. ${ }^{26}$ Preferensi penggunaan minyak mentah sebagai bentuk pembayaran oleh pemerintah Sudan dilihat sebagai bentuk lain dari investasi minyak Cina di Sudan. Dengan begitu, Cina tetap akan mendapatkan pasokan minyak dari Sudan selain dari kerjasama eksplorasi dan produksi minyak di selatan Sudan. Bentuk pinjaman yang menggunakan sumber daya sebagai alat pembayaran disebut sebagai resource-backed development loans.

\section{Dampak Investasi Cina di Sudan}

Perang sipil yang melanda Sudan bagian selatan mendapatkan perhatian dunia internasional setelah konflik Darfur mencuat sebagai isu pelanggaran hak asasi manusia. Konflik yang bertahun-tahun mengganggu stabilitas keamanan di selatan Sudan ini pada akhirnya menemukan perdamaian pada tahun 2004. Meski demikian, kondisi pasca-konflik yang masih dipenuhi kecurigaan tinggi di dalam masyarakat Sudan khususnya Sudan Selatan telah membuat CNPC dan pemerintah Cina khawatir karena sebagian besar sumur minyak yang dikuasai CNPC berada di selatan Sudan di daerah konflik. Sudanese People Liberation Army (SPLA) yang seringkali mengatasnamakan warga sipil Sudan Selatan menuduh kehadiran Cina di Sudan Selatan memperburuk situasi yang telah mengalami efek yang sangat merugikan dari adanya perang utara-selatan ini.

Selama perang sipil tersebut berlangsung, Cina merupakan pemasok utama persenjataan untuk militer Sudan termasuk amunisi persenjataan, helikopter, pesawat tempur, tank T-59, senjata anti-pesawat kaliber $37 \mathrm{~mm}$ dan howitzer kaliber $122 \mathrm{~mm}, 220$ truk

\footnotetext{
26 Maglad, Nour Eldin A. "Scoping Study on Chinese Relations with Sudan." Impact of China and India on Sub-Saharan Africa: Scoping Studies on China-Africa Economic Relations. (Dar-es-Salaam: AERC. 2008) 1-29.
} 
127 Fajar Ajie Setiawan Memahami Investasi Berbasis Minyak Cina Di Sudan: Analisis Interaksi Strategis Cina Pada Situasi Konflik

militer yang dibayar oleh pemerintah Sudan menggunakan minyak hasil produksi domestik. Selain itu, Cina juga menjual beberapa pesawat tempur buatan Shenyang dan 12 jet supersonic F-7. Cina juga menanamkan investasinya di dalam pembangunan tiga pabrik senjata di Sudan. Selain melalui suplai persenjataan, Cina juga seringkali menghimbau pemerintah Sudan untuk mengirimkan pasukan militernya ke daerah-daerah dimana CNPC beroperasi, seringkali dengan bantuan tentara Cina tanpa seragam dan tentara Sudan. ${ }^{27}$

Keterlibatan Cina dengan militer Sudan menyebabkan terjadinya penyeranganpenyerangan yang dilakukan SPLA terhadap instalasi minyak Cina di Sudan bagian selatan. Penyerangan ini juga dilakukan oleh SPLA untuk melemahkan posisi militer Sudan sehingga perang sipil dapat diakhiri. Selain itu, penyerangan-penyerangan ini juga dilakukan sebagai reaksi atas pelanggaran hak asasi manusia yang dilakukan pemerintah Sudan di daerah selatan, yang membantai dan mengusir warga lokal dari tanah mereka untuk membuka lahan pengeboran minyak. Keterlibatan Cina di Sudan menimbulkan tekanan dari publik internasional, menuduh Cina sebagai aktor penting perekonomian dunia yang tidak bertanggung jawab dengan membantu pemerintah Sudan, seringkali bersikap abstain di dalam upaya pembentukan Resolusi DK PBB terkait kondisi di Sudan. Sikap Cina dilihat sebagai bentuk upaya Cina untuk tetap mendapatkan suplai minyak dari Sudan, meskipun tuduhan 'tidak bertanggung jawab' semakin keras diserukan oleh pengamat situasi di Sudan seperti PBB, Amerika Serikat, negara-negara Eropa, serta NGO kemanusiaan. Pada akhirnya, sikap Cina ini berakhir pada tahun 2011 ketika referendum dilakukan di Sudan bagian Selatan dan Cina akhirnya mendukung referendum ini.

\footnotetext{
27 "China's Overseas Investment in Oil and Gas Production". 22-23.
}

\section{Analisis dan Diskusi}

Perilaku non-interferensi Cina di Sudan dilihat sebagai sebuah kebijakan yang persisten dan tidak bertanggung jawab oleh dunia internasional. Cina seharusnya ikut memberikan andil terhadap keamanan dunia dan perlindungan HAM, yang merupakan nilai-nilai universal yang dituju di dalam Piagam PBB dan keanggotaan DK PBB. Bagian ini akan menganalisis dan menjelaskan faktor-faktor yang mendorong investasi Cina di Sudan. Faktor-faktor tersebut dapat dijelaskan melalui pendekatan ekonomi politik internasional, yang menekankan pentingnya hubungan domestik-internasional dengan berdasar kepada kepentingan nasional, institusi, dan informasi.

\section{Kepentingan Negara}

Cina mengalami pertumbuhan ekonomi yang stabil antara 8-10\% semenjak 1978 yang akan dapat dipertahankan hingga 10 tahun mendatang apabila tren saat ini dapat dipertahankan. ${ }^{28}$ Pada tahun 2011, 20\% dari total konsumsi energi Cina adalah minyak bumi. $^{29}$ Penggunaan minyak bumi ini diperkirakan akan terus meningkat mengingat penggunaan batu bara yang dinilai Cina sebagai sumber energi murah terus mendapat perhatian dunia internasional terkait dengan polusi yang dihasilkan. Selain itu, penggunaan minyak bumi merupakan alternatif yang paling memungkinkan bagi Cina apabila dibandingkan dengan sumber-sumber energi lainnya seperti energi nuklir.

28 Stephen C. Thomas. "China's Economic Development from 1860 to the Present: The Roles of Sovereignty and the Global Economy." Forum on Public Policy 2007, No. 1, (2006): 2729.

29 Paul Crompton and Yanrui Wu. "Energy Consumption in China: Past Trends and Future Directions." Energy Economics 27, no. 1 (2005): 195-208 
128 Fajar Ajie Setiawan Memahami Investasi Berbasis Minyak Cina Di Sudan: Analisis Interaksi Strategis Cina Pada Situasi Konflik

Gambar 2 Produksi dan Konsumsi Domestik Minyak Bumi Cina 1991-2010 (dalam ribu barel per hari)

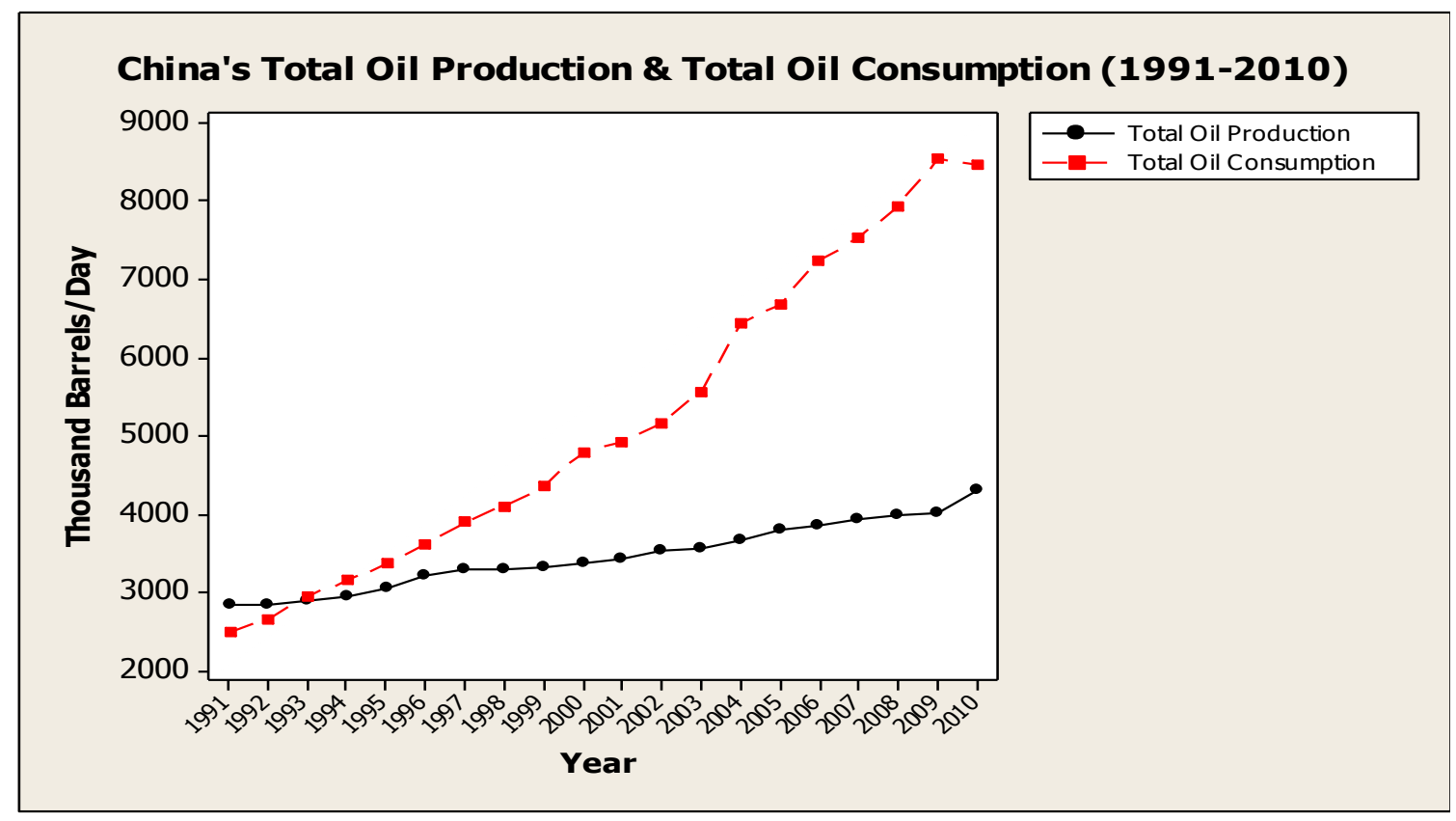

Sumber: Diolah dari berbagai sumber

Bila dilihat dari grafik, Cina tidak dapat memenuhi konsumsi domestik minyak bumi semenjak tahun 1993. Hal ini menjadi perhatian pemerintah Cina karena sumber energi lain hanya akan memenuhi sedikit dari kebutuhan konsumsi minyak Cina saat ini dan masa depan. Oleh karena itu, muncullah ketergantungan Cina terhadap sektor minyak luar negeri.

Produksi minyak di Cina stabil di angka 2.836.20 thousand barrels per day (tbpd) di tahun 1991 menjadi 3.377.50 tbpd di tahun 2000 dan terakhir di angka 4.308.40 pada tahun 2010. Produksi domestik minyak bumi Cina terfokus pada dua sumur minyak terbesar di Cina yaitu di Daqing (Heilongjiang) dan Tarim (Xinjiang). Meski demikian, kebutuhan konsumsi Cina melonjak drastis dari tahun 1991 menuju tahun 2010 dengan 2.498 .80 di tahun 1991 menjadi 8.745.70 di tahun 2010. Hal ini dapat dijelaskan dengan melihat rata-rata konsumsi minyak bumi di Cina dalam kurun waktu 20 tahun tersebut adalah sebesar 5200 tbpd, jauh di atas produksi domestik Cina. Konsumsi yang sangat besar ini tidak dapat diimbangi oleh produksi domestik sehingga mendorong Cina untuk mengimpor minyak dari luar negeri secara besar-besaran seperti yang terlihat di dalam grafik di bawah ini. 
129 Fajar Ajie Setiawan Memahami Investasi Berbasis Minyak Cina Di Sudan: Analisis Interaksi Strategis Cina Pada Situasi Konflik

Gambar 3 Ekspor dan Impor Minyak Bumi Cina 1991-2010 (dalam ribu barel per hari)

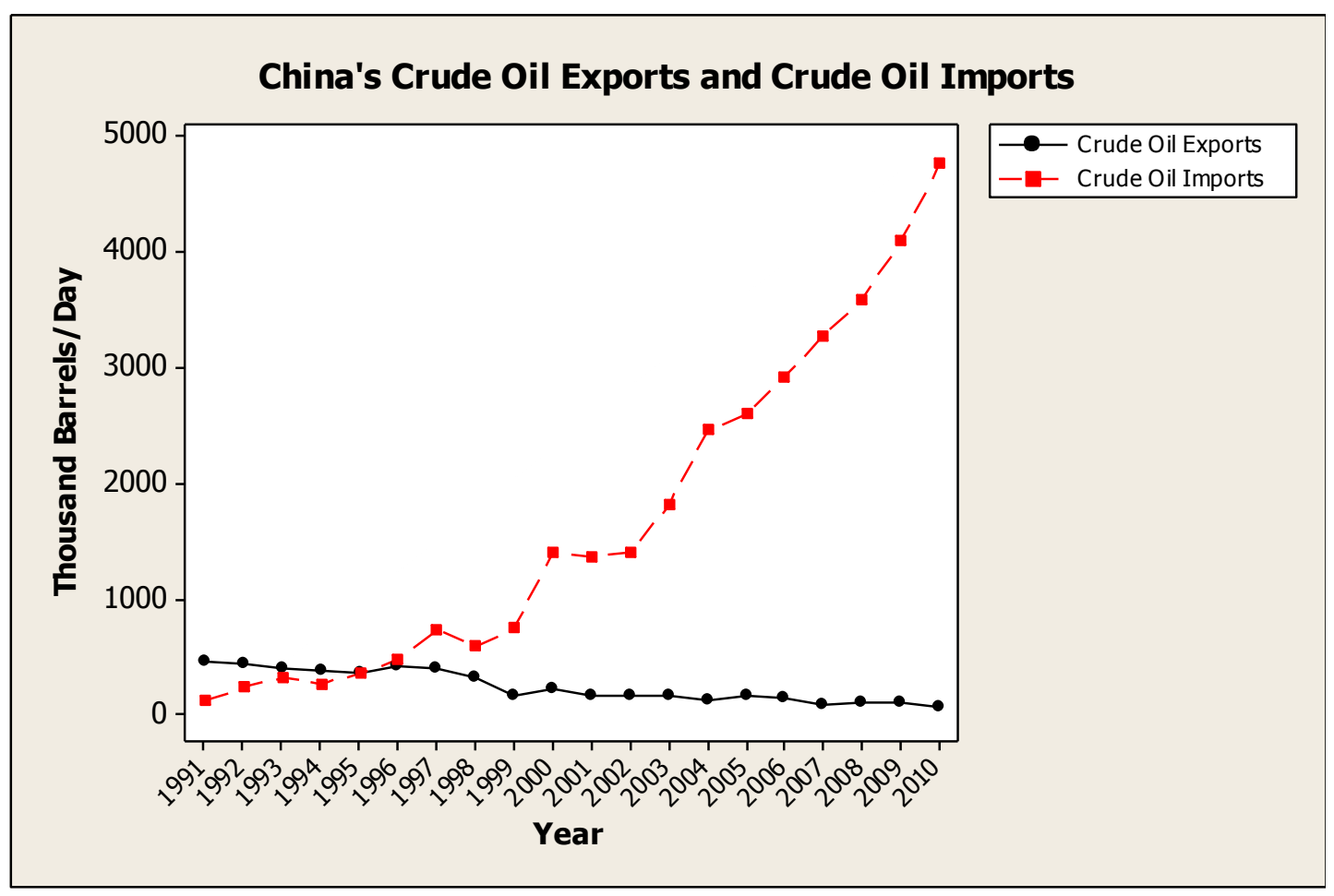

Sumber Diolah dari berbagai sumber

Seperti yang terlihat di grafik, impor minyak Cina melonjak dari 121 tbpd pada tahun 1991 menjadi 4.753,64 tbpd pada tahun 2011, hampir dua belas kali lipat dari tahun 1991. Impor minyak besar-besaran ini memenuhi lebih dari setengah kebutuhan harian minyak bumi Cina sebesar $8.475,70$ tbpd. Impor ini juga menjadikan Cina sangat tergantung kepada suplai minyak luar negeri, yang menjadi sebuah ancaman keamanan energi Cina. Hal ini akan mendorong Cina untuk mengamankan suplai minyak luar negeri dengan segala cara agar suplai tidak terganggu dan stabilitas domestik dapat terjaga.

Isu konsumsi Cina menjadi faktor pertama mengapa Cina melakukan kerjasama non-interferensi dengan Sudan. Penelitian ini berargumen bahwa Cina berusaha untuk mengamankan sumber energi minyak bumi dengan Sudan dengan tidak melihat permasalahan domestik Sudan sebagai isu yang perlu ditangani, yang selama ini memaksa pihak asing lainnya seperti Amerika Serikat dan Eropa untuk tidak menanamkan modal dan mengusahakan suplai dari pemerintah Sudan. Apabila Cina mengubah pendekatannya, dapat dipastikan hubungan diplomasi dan ekonomi Cina-Sudan akan terganggu, sehingga kepentingan nasional Cina terkait energi minyak tidak dapat dipenuhi dan dapat mengancam keamanan Cina.

\section{Spesifikasi Setting Strategis}

Spesifikasi setting strategis yang dilakukan Cina, atau dalam kata lain, struktur interaksi yang dibentuk oleh Cina dalam memenuhi kepentingan ekonominya akan minyak bumi dilakukan dengan dua hal: 1) kebijakan non-interferensi/postur permisif terhadap isu domestik Sudan; dan 2) aplikasi strategic trade policy dengan menggunakan SOE Cina di Sudan. Pemerintah Cina terlibat secara aktif terkait dengan proses negosiasi dan pembentukan hubungan baik Cina-Sudan. 
130 Fajar Ajie Setiawan Memahami Investasi Berbasis Minyak Cina Di Sudan: Analisis Interaksi Strategis Cina Pada Situasi Konflik

Kebijakan non-interferensi ini dapat dilihat sebagai salah satu implementasi kebijakan luar negeri Cina yaitu "Dahulukan Cina". Kebijakan ini memfokuskan kepada pemenuhan kebutuhan dan kepentingan nasional Cina sebagai yang utama dan hubungan-hubungan kerjasama luar negeri yang dibentuk terbatas kepada hal tersebut. Prinsip non-interferensi kemudian berlaku sebagai implementasi kebijakan untuk memastikan bahwa kepentingan nasional Cina menjadi utama dan terpenuhi dengan tidak melihat isu-isu lain yang dianggap dapat mempengaruhi pemenuhan kepentingan nasional ini.

Kebijakan non-interferensi dengan Sudan berarti bahwa hubungan Cina-Sudan terbatas pada bisnis: minyak bumi. Bahkan bantuan luar negeri dan pinjaman luar negeri yang diberikan Cina, termasuk penjualan persenjataan militer merupakan salah satu strategi Cina untuk memenuhi kepentingan nasional Cina di Sudan yaitu minyak bumi melalui pembayaran yang dilakukan oleh Sudan dalam bentuk sumber energi tersebut.

Sebagai tambahan, kebijakan "Dahulukan Cina" dapat terlihat dari penggunaan warga nasional Cina sebagai top management di dalam proyek-proyek Cina di Sudan. Hal ini memperlihatkan bahwa Cina benar-benar berusaha memenuhi kebutuhan nasionalnya, bahkan termasuk memastikan hal tersebut melalui penggunaan sumber daya manusia yang didatangkan dari Cina untuk beroperasi di Sudan, yang membentuk 20\% dari jumlah keseluruhan pegawai yang bekerja untuk proyek-proyek Cina di Sudan. ${ }^{30}$

\section{Penggunaan State-Owned Enterprise} (SOE) sebagai kepanjangan tangan pemerintah Cina di luar negeri merupakan usaha Cina

\footnotetext{
${ }^{30}$ Deborah Brautigam.. "Africa's Eastern Promise." Foreign Affairs 5, (2010) diakses melalui http://www.foreignaffairs.com/articles/65916/deb orah-brautigam/africa\%E2\%80\%99s-easternpromise? page=show pada 3 September 2017.
}

untuk menarik kapital yang mungkin didapatkan pihak luar negeri ke dalam domestik Cina. Hal ini dapat dijelaskan melalui teori Strategic Trade Policy atau Strategic Trade Theory yang melihat bahwa sebuah negara akan berusaha menarik keuntungan luar negeri ke dalam domestik. Salah satu bentuknya adalah penggunaan SOE oleh Cina untuk menarik devisa. ${ }^{31}$

Penggunaan SOE di Sudan dilakukan Cina melalui CNPC yang bertanggung jawab pada sektor hulu minyak di Sudan. Selain sebagai sebuah mesin bisnis, CNPC (dan SOE pada umumnya) merupakan instrumen diplomasi Cina di luar negeri. Penggunaan CNPC sebagai instrumen merupakan usaha Cina untuk mendapatkan suplai minyak yang dapat diandalkan, lancar, dan murah. Ketiga hal ini menjadi penting bagi pemerintah Cina karena keberadaan tiga faktor sumber daya minyak ini merupakan faktor yang menjaga kestabilan domestik Cina. Apabila suplai minyak terganggu, Cina sebagai negara yang sangat bergantung kepada minyak luar negeri akan mengalami kemandekan perkembangan pertumbuhan ekonomi karena sektor industri terganggu. Selain itu, apabila harga minyak melonjak juga akan mengganggu proses ekonomi domestik yang ditakutkan pemerintah Cina akan meresahkan masyarakat dan mengancam status quo Partai Komunis Cina (PKC) sebagai pemegang kekuasaan di Cina.

\section{Perhatian terhadap Ketidakpastian Situasi}

Cina mulai menyesuaikan kebijakan luar negerinya terhadap Sudan setelah Konflik Sudan mendapatkan perhatian dunia internasional, dengan Presiden Al-Bashir mendapatkan tuduhan sebagai penjahat perang dan diusulkan untuk diadili di Pengadilan Internasional. Pada awalnya Cina bereaksi keras terhadap tuduhan ini, namun perubahan mulai terjadi pada tahun 2007. Ada tiga alasan

\footnotetext{
${ }^{31}$ Robert Gilpin, Global Political Economy, Op.cit. hal. 122-127.
} 
131 Fajar Ajie Setiawan Memahami Investasi Berbasis Minyak Cina Di Sudan: Analisis Interaksi Strategis Cina Pada Situasi Konflik

perubahan kebijakan luar negeri Cina terhadap Sudan. Pertama, Cina semakin menunjukkan sensitivitas tinggi atas tuduhan negatif dunia internasional terhadap perilakunya di dunia internasional. Semakin tingginya sentimen negatif terhadap Cina pada dasarnya akan mengganggu upaya Cina untuk melakukan ekspansi ekonomi dan pengaruh, suatu hal yang dianggap penting bagi Beijing, serta mempertajam ketidakpastian (misinformasi, berbedanya situasi yang dihadapi Cina dengan skenario yang diperkirakan sebelumnya). ${ }^{32}$

Kedua, pengkajian ulang terhadap kepentingan nasional dan politik Cina yang mengubah pendekatan Cina di dunia internasional. Hal ini terutama disebabkan oleh adanya perubahan situasi dunia internasional terkait isu Sudan yang dianggap di luar skenario diplomasi Cina, serta perubahan kapasitas Cina dari negara berkembang menjadi sebuah negara great power yang memiliki peranan penting di dunia internasional yang menuntut Beijing untuk memosisikan ulang Cina baik di dalam hubungannya dengan Sudan maupun dalam sistem ekonomi internasional. ${ }^{33}$

Ketiga, dan merupakan titik perubahan kebijakan Cina pada tahun 2007 adalah semakin meningkatnya serangan-serangan pemberontak terhadap instalasi milik Cina dan juga warga negara Cina, dengan serangan yang paling fatal adalah serangan terhadap instalasi minyak di Kodorfa pada Oktober 2007 dan penculikan warga Cina pada Oktober 2008 yang kemudian dibunuh oleh pemberontak. ${ }^{34}$ Meningkatnya serangan ini merupakan sebuah faktor ketidakpastian di dalam investasi Cina

\footnotetext{
${ }^{32}$ Stephanie Kleine-Ahlbrandt dan Andrew Small, "China, the unlikely human rights champion," Policy Innovations, diakses melalui http://www.policyinnovations.org/ideas/comment ary/data/HumanRightsChampion pada 16 Desember 2016.

${ }^{33}$ Ibid.

${ }^{34}$ China's Sudan Engagement: Changing Northern and Southern Political Trajectories in Peace and War. Op.cit.
}

yang justru semakin mengancam kepentingan Cina dan kebutuhannya akan minyak bumi. Ketiga faktor ini mengubah pendekatan Cina terhadap Sudan menjadi lebih pragmatis dan aktif di dalam menuntut penyelesaian konflik Darfur.

\section{Kesimpulan}

Berdasarkan hasil analisis yang dilakukan dengan menggunakan teori interaksi strategis antar negara, investasi berbasis minyak Cina di Sudan sangat erat kaitannya dengan kepentingan nasional Cina, bagaimana Cina memainkan peranannya di dunia internasional pada kurun waktu tersebut berdasarkan kebijakan "China First" yang memprioritaskan kepentingan nasional Cina terkait dengan perkembangan ekonominya, serta adanya perubahan kebijakan luar negeri dan postur internasional Cina. Hubungan ini dapat dijelaskan melalui tiga variabel yaitu: 1) kepentingan nasional Cina di Sudan yaitu suplai minyak terkait dengan kebutuhan impor minyak Cina yang sangat krusial bagi perkembangan ekonomi Cina; 2) spesifikasi setting strategis kebijakan ekonomi luar negeri (foreign economic policy) Cina yang berdasarkan kepada "China First" dengan dasar kebijakan non-interferensi dan penggunaan institusi SOEs sebagai instrumen negara untuk mencapai kepentingannya di Sudan; dan 3) adanya perubahan kebijakan ekonomi luar negeri ini dalam kurun 20102011 terkait dengan perubahan situasi di Sudan yang dapat dihubungkan dengan ketidakpastian yang dihadapi oleh Cina. Hingga awal dekade 2000, Cina mempertahankan pendekatan ini dengan tujuan mengamankan kepentingan nasionalnya di Sudan. Namun, perubahan di dalam postur Cina di ranah internasional, tekanan yang tinggi terhadap perilaku Cina di Sudan, serta meningkatnya serangan-serangan terhadap instalasi minyak milik Cina oleh SPLA mendorong Cina pada akhirnya untuk mengubah pendekatan non-interferensi ini menjadi lebih pragmatis dan pro-perdamaian. 
132 Fajar Ajie Setiawan Memahami Investasi Berbasis Minyak Cina Di Sudan: Analisis Interaksi Strategis Cina Pada Situasi Konflik

Derajat ketidakpastian yang semakin tinggi ini (atau justru informasi terhadap proses pembentukan kebijakan yang semakin jelas) baik yang berasal dari domestik Sudan maupun dari tekanan dunia internasional mendorong Cina mengubah posisi kehadirannya di Sudan. Hal ini khususnya terlihat dari semakin menurunnya impor minyak bumi Cina di Sudan sebesar 10\% dari tahun 2012-2017, setelah Cina mulai mengubah kebijakannya. ${ }^{35}$

\section{Daftar Pustaka}

\section{Buku:}

- 1987. The Political Economy of International Relations. New Jersey: Princeton University Press.

Abdelal, Rawi, Mark Blyth, dan Craig Parsons, . 2010. Constructing the International Economy. New York: Cornell University Press.

Blyth, Mark, penyunt. 2009. Routledge Handbook of International Political Economy (IPE). New York: Routledge.

Cohen, Benjamin J. 2009. "The Multiple Traditions of American IPE." Dalam Routledge Handbook of International Political Economy (IPE), disunting oleh Mark Blyth, 23-35. New York: Routledge.

Crompton, Paul, dan Yanrui Wu. 2005. "Energy Consumption in China: Past Trends and Future Directions." Energy Economics 27 (1): 195-208.

Frieden, Jeffry A., dan Ronald Rogowski. 1996. "The Impact of the International Economy on National Policies: An Analytical Overview." Dalam Internationalization and Domestic

\footnotetext{
35 Crude Oil Imports by Country, World's Top Exports, diakses melalui http://www.worldstopexports.com/crude-oilimports-by-country/ pada 6 September 2017.
}

Politics, disunting oleh Robert O. Keohane dan Helen V. Milner, 25-47. Cambridge: Cambridge University Press.

Frieden, Jeffry, dan Lisa L. Martin. 2001. "International Political Economy: Global and Domestic Interactions." Dalam Political Science: The State of Discipline, oleh Ira Katznelson dan Helen Miller, 118-146. Boston: W. W. Norton \& Company.

Gilpin, Robert. 2001. Global Political Economy: Understanding the International Economic Order. New Jersey: Princeton University Press.

Jackson, Robert, dan Georg Sorensen. 2006. Introduction to International Relations Theories and Approaches. 3rd. Oxford: Oxford University Press.

Keohane, Robert O., dan Helen V. Milner, . 1996. Internationalization and Domestic Politics. Cambridge: Cambridge University Press.

Oatley, Thomas H. 2016. International Political Economy. 5th. New York: Routledge.

Shirk, Susan. 1996. "Internationalization and China's Economic Reforms." Dalam Internationalization and Domestic Politics, disunting oleh Robert O. Keohane dan Helen V. Milner, 186208. Cambridge: Cambridge University Press.

Spero, Joan E., dan Jeffrey A. Hart. 1997. The Politics of International Economic Relations. 5th. London: Routledge.

\section{Jurnal:}

Chen, Shaofeng. 2010. "China's SelfExtrication from the "Malacca Dilemma" and Implications." International Journal of China Studies 1 (1): 1-24. 
Manyok, Phillip. 2016. "Oil and Darfur's Blood: China's Thirst for Sudan's Oil." Journal of Political Science \& Public Affairs 4: 189.

Shinn, David H. Fall/Winter 2009. "China and the Conflict in Darfur." Brown Journal of World Affairs XVI (1): 85-100.

\section{Lain-lain:}

BBC. t.thn. China in Africa: Developing Ties. Diakses September 6, 2017. http://news.bbc.co.uk/1/hi/world/africa 17086777.stm.

Brautigam, Deborah. 2010. “Africa's Eastern Promise." Foreign Affairs 5.

Chin, Gregory, Margaret M. Pearson, dan Wang Yong. 2013. "Introduction IPE with China's characteristics." Review of International Political Economy 20 (6): 1145-1164.

International Crisis Group. 2012. China's New Courtship in South Sudan. Africa Report, Brussels: International Crisis Group.

Large, Daniel. 2009. "China's Sudan Engagement: Changing Northern and Southern Political Trajectories in Peace and War." The China Quarterly 199:

610-626. doi:10.1017/S0305741009990129.

Maglad, Nour Eldin A. 2008. "Scoping Study on Chinese Relations with Sudan." Impact of China and India on SubSaharan Africa: Scoping Studies on China-Africa Economic Relations. Dar-es-Salaam: AERC. 1-29.

Morrison, Wayne M. 2017. China's Economic Rise: History, Trends, Challenges, Implications for the United States. Washington D.C.: Congressional Research Service.
Thomas, Stephen C. 2006. "China's Economic Development from 1860 to the Present: The Roles of Sovereignty and the Global Economy." Forum on Public Policy 2007 (1): 27-29.

US-China Economic and Security Review Commission. 2006. China's Overseas Investment in Oil and Gas Production. Government Publication, Washington D.C.: Eurasia Group.

Wenjie, Chen, David Dollar, dan Heiwai Tang. 2016. "Why is China investing in Africa? Evidence from the firm level." The World Bank Economic Review lhw049. 